ISAHP Article: García-Melón, Poveda- Bautista, Del Valle/Using Alignment with Corporate Strategy for the selection of a Project Portfolio based on ANP. To Be Submitted to the International Symposium of the Analytic Hierarchy Process 2014, Washington D.C., U.S.A.

\title{
USING ALIGNMENT WITH CORPORATE STRATEGY FOR THE SELECTION OF A PROJECT PORTFOLIO BASED ON ANP
}

\author{
Mónica García-Melón a \\ mgarciam@dpi.upv.es \\ Rocío Poveda-Bautista ${ }^{\mathrm{a}}$ \\ ropobau@upvnet.upv.es \\ ${ }^{a}$ Departamento de Proyectos de Ingeniería \\ Universitat Politècnica de València \\ Camino de Vera s/n \\ 46022 Valencia (Spain) \\ José L. Del Valle M. \\ Universidad Metropolitana de Caracas \\ Caracas 1071, Edo Miranda (Venezuela) \\ josedelvalle@mac.com
}

\begin{abstract}
In this paper a new approach to prioritize project portfolio in an efficient and reliable way is presented. The research methodology is based on a combination of a synthesis of the literature across the diverse fields of project management, project alignment, multicriteria decision methods and a parallel analysis of an industrial case study.

The paper introduces a rigorous methodology with acceptable complexity which seeks to assist managers of the National Electricity Corporation of Venezuela (Corpoelec) in their yearly resources' assignment on their projects portfolio. The aim being to determine the degree of alignment of each project to corporate strategy based on the judgments of a group of experts on the expected contribution of the projects to the business strategic objectives. The model presented can be used both as a descriptive and a prescriptive model.

The approach presented uses project prioritization based on the multi-criteria decisionmaking technique called Analytic Network Process. Thus the corporate strategic objectives will be used as prioritization criteria to obtain the Relative Alignment Index (RAI).
\end{abstract}

Keywords: ANP, decision making, project portfolio, Strategic Alignment of Projects.

\section{Introduction}

Organizations using projects as ways to develop corporate strategies believe that the most complex phase of the process is strategy implementation. Cause of this complexity is failing in establishing adequate relationships between business strategy and project portfolio management, that is called "strategic alignment". This issue can be analyzed using the general model proposed by Meskendahl (2010) and can be seen as disconnection between Strategic Orientation and Project Portfolio Structuring. According to Mankins and Steele (2005), this disconnection may cause organizations to barely accomplish a $63 \%$ of the total potential value of their strategies or, as suggested by Johnson (2004), only $44 \%$ of the corporate strategy is actually implemented. Since these 
IJAHP Article: Mu, Saaty/A Style Guide for Paper Proposals To Be Submitted to the International Symposium of the Analytic Hierarchy Process 2014, Washington D.C., U.S.A.

results are evident in the execution phase of a project, organizations have focused on project portfolio management and the direct relationships between the projects of the portfolio and the strategic objectives of the organization (Artto and Dietrich, 2004; Dietrich and Lehtonen, 2005).

\section{Literature Review}

Project prioritization consists on assigning priority or rank order to projects within a portfolio based on a set of priority criteria, whose diversity and classification has been addressed by several authors. These studies have determined the influence of portfolio prioritization as a key factor for business success (Fricke et al., 2000).

Project prioritization is a multidimensional process because it involves a wide range of criteria: technical, economic, social, political and environmental (Meade, 2002; Dey, 2006), and the complex relationships among them. It should consider the interdependence of the projects in the portfolio to assess not only the importance of the projects for the achievement of business strategy, but also the influence of certain projects on the other projects of the same portfolio (Killen and Kjaer, 2012).

Alignment is a concept addressed in the literature on project portfolio management (Srivannaboon and Milosevic, 2006) and is defined as the degree to which a project contributes to business strategy.

Several authors and researchers have addressed the prioritization of projects in engineering using MCDA techniques. Most MCDA techniques assume the criteria have not dependencies between them. In this case -the projects in a portfolio- are strongly related, as suggested by Killen and Kjaer (2012). A method based on ANP may capture these relationships whose analysis with other multicriteria techniques might be incomplete since they are not able to consider influences among strategic objectives and projects.

\section{Hypotheses/Objectives}

In this paper we want to go one step further and present a model to address these shortcomings based on the following assumptions:

a) Project prioritization is a multidimensional process (Meade, 2002)

b) Project prioritization should consider the interdependence of the projects in the portfolio to assess not only the importance of the projects for the achievement of business strategy, but also the influence of certain projects on the other projects of the same portfolio (Killen and Kjaer, 2012)

c) The information required for project prioritization can be qualitative, subjective and probabilistically or lexically uncertain (Ghapanchi et al, 2012); consequently the prioritization process involves making estimates.

d) Experience and knowledge of the agents involved in the prioritization process is as important as the methodology itself; therefore a key factor is the right selection of experts.

In this paper, we propose a way to rank projects of company's portfolio according of their strategic alignment. That means, to measure the estimated contribution of a given project to the achievement of the company's strategy. According to its level of alignment each project will be ranked.

\section{Research Design/Methodology}


IJAHP Article: Mu, Saaty/A Style Guide for Paper Proposals To Be Submitted to the International Symposium of the Analytic Hierarchy Process 2014, Washington D.C., U.S.A.

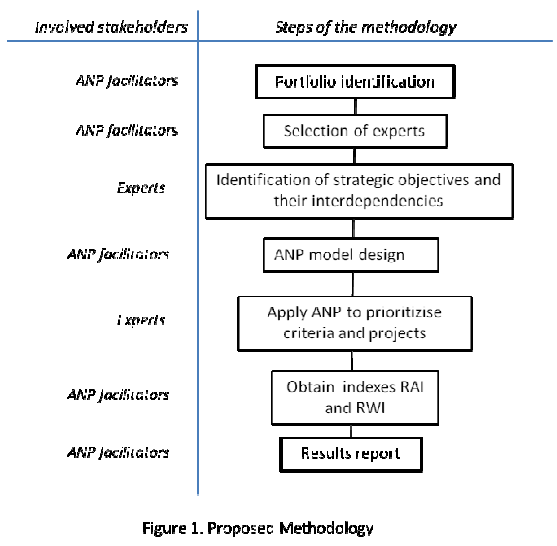

The Relative Alignment Index (RAI) is defined as the normalized dimensionless priority value of each project obtained with ANP using the strategic objectives of the organization as prioritization criteria, and the Relative Weight Index (RWI) is defined as the dimensionless priority value of each criterion over the others obtained in ANP-step (v). The steps of the proposed methodology are:

Step (i). Project identification

Identify projects portfolio that possibly contribute to business strategy. Projects included in Technology Master Plan portfolio are shown in Table 1.

Table 1. Technology Master Plan Portfolio. Source: compiled by authors.

\begin{tabular}{|c|c|c|}
\hline Code & Project & Description \\
\hline PT001 & $\begin{array}{l}\text { Corpoelec Unique Business Management } \\
\text { System }\end{array}$ & $\begin{array}{l}\text { Implementation of a unique business management system (ERP) administered by } \\
\text { ATIT Corpoelec, that consolidates the adminisistrative support functions of the old } \\
\text { operators. }\end{array}$ \\
\hline PT002 & $\begin{array}{l}\text { Adaptation of the system that supports the } \\
\text { commercial management of Corpolec }\end{array}$ & $\begin{array}{l}\text { Adecauacy of infrastructures and computer systems of the commercial offices with the } \\
\text { highest sales revenues and correction of } 9 \text { faults } \\
\text { (SCC.Adentified in OPEN system }\end{array}$ \\
\hline PT003 & Corpoelec Data Network Integration system & $\begin{array}{l}\text { Updating and Integration of the different data networks of the old electrical operators } \\
\text { into one national network run by ATIT Corpoelec }\end{array}$ \\
\hline PT004 & $\begin{array}{l}\text { Integration of Corpoelec Telephone } \\
\text { Sustems }\end{array}$ & $\begin{array}{l}\text { Updating and Integration of the telephone systems of the old electrical operators in a } \\
\text { sincle national telephone svstem administered by ATIT Corpoelec }\end{array}$ \\
\hline PT005 & $\begin{array}{l}\text { Integration of Corpoelec Radio } \\
\text { Communication Systems }\end{array}$ & $\begin{array}{l}\text { Updating and Integration of the radio systems of the old electrical operators in a } \\
\text { single national radio communication network administered by ATII Corpoelec }\end{array}$ \\
\hline PT006 & Services Management system & 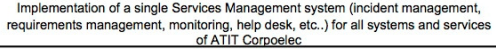 \\
\hline PT007 & Global Data Center & $\begin{array}{l}\text { Adaptation of a Giobal Data Center and Design, procurement, construction and } \\
\text { implementation of a Support Datata Center fort the support of all systems and sevices } \\
\text { of AATT Corpceelec }\end{array}$ \\
\hline PT008 & $\begin{array}{l}\text { Integration of Corpoelec data transport } \\
\text { systems }\end{array}$ & $\begin{array}{l}\text { Updating and integration of the different data transport systoms of the old electrical } \\
\text { operators in a single national cata transport network administered by ATIT Corpoelec }\end{array}$ \\
\hline PT009 & Knowledge Management System & Implementation of a document and knowledge management system for Corpoelec \\
\hline PT010 & Operations Management System & $\begin{array}{l}\text { Implementatain of an operations managagement system for the managememnt of } \\
\text { Generation Plants, the National Office, Regiogiol OOffices and Distribution Offices } \\
\text { netionwide. }\end{array}$ \\
\hline PT015 & Corpoelec unique email system & $\begin{array}{l}\text { Implementation of a unique emall system (@ corpoelec.gob.ve) that replaces of the } \\
\text { email systems of the old operators. }\end{array}$ \\
\hline
\end{tabular}

Step (ii). Selection of experts

They should have enough expertise to understand the problem on stake and know the company from different perspectives.

Experts were interviewed and they were informed on the ANP methodology and on the characteristics of the problem to solve and were asked to participate in the whole procedure. 
IJAHP Article: Mu, Saaty/A Style Guide for Paper Proposals To Be Submitted to the International Symposium of the Analytic Hierarchy Process 2014, Washington D.C., U.S.A.

Table 2. Selected experts. Source: compiled by authors

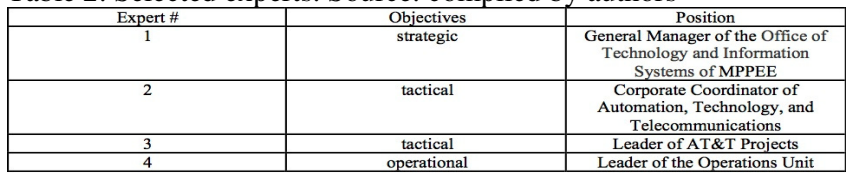

Step (iii). Identification of strategic objectives and their relationships

The strategic objectives were part of the general corporate strategy of Corpoelec. These objectives are:

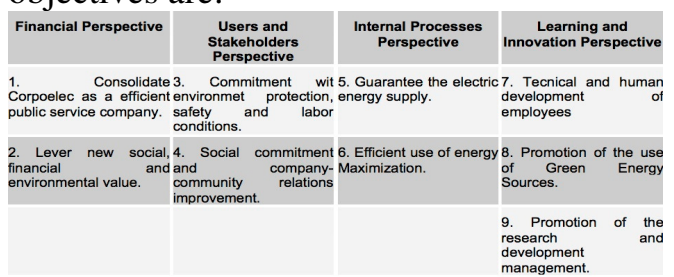

Figure 2. Corpoelec Strategic Goals. Source: compiled by authors

The four Balanced Scorecard (BSC) perspectives are used in this methodology to systematically formulate a set of strategies and strategic objectives that help the company achieve its general goals. The relationships among the strategic objectives were obtained with the help of the experts.

Step (iv). ANP model design and application

Corporate strategic objectives will be used as prioritization criteria for the ANP model. The BSC management system will be used to cluster these criteria. Judgments of the experts will be elicited by means of questionnaires and processed in order to obtain results. The main step in this methodology is the determination of the influence of some elements over other. To achieve that a face-to-face meeting with the four experts was hold meeting to determine the relationships between objectives. The results were obtained by consensus among experts.

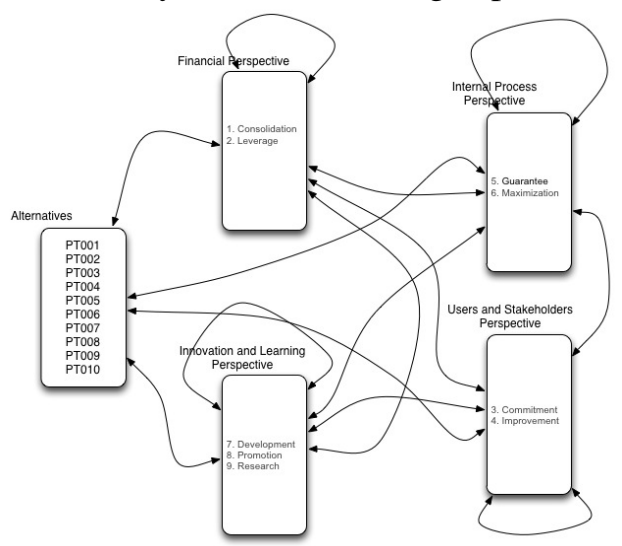

Figure 3. ANP network for the case study. Source: compiled by authors

All this data were computed with software Superdecisions which allowed us to obtain the individual results as well as the consistency index (CI) that was less than 0.1 for each expert. As said before and according to Saaty, these individual results were aggregated by means of the geometric mean to obtain the group results. 
IJAHP Article: Mu, Saaty/A Style Guide for Paper Proposals To Be Submitted to the International Symposium of the Analytic Hierarchy Process 2014, Washington D.C., U.S.A.

Step (v). Obtaining indexes RAI and RWI

The Relative Alignment Index (RAI) for each project (alternative) and the Relative Weight Index (RWI) for each strategic objective (criterion) will be obtained.

\section{Data/Model Analysis}

Table 3. Limit Supermatrix

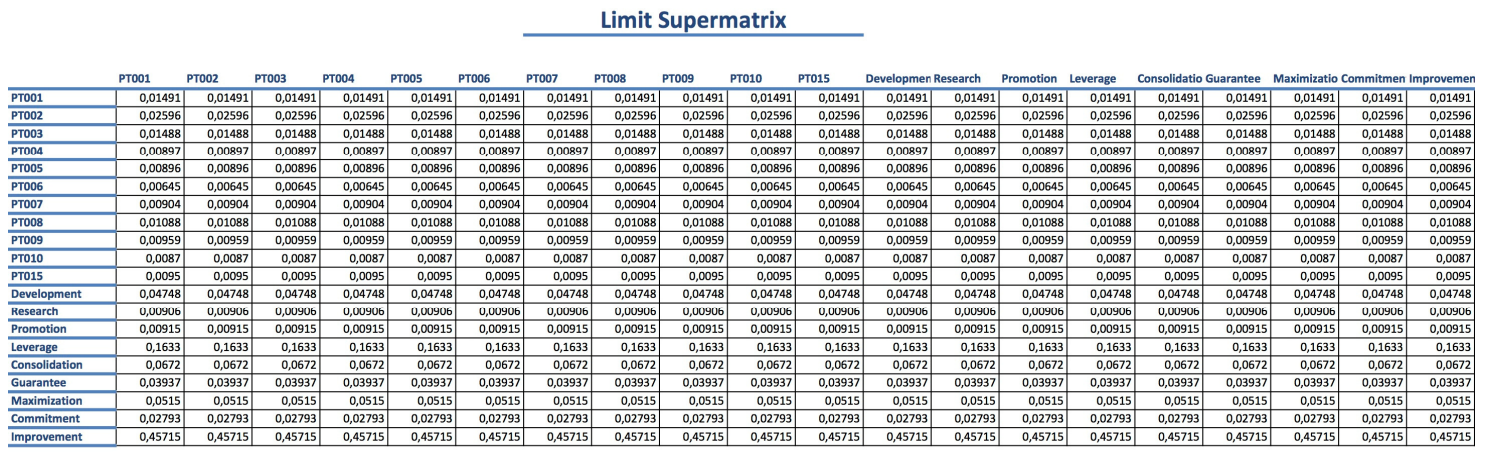

Table 4. Ranking of projects according to their RAI

Table 5. Ranking of Objectives according to RWI

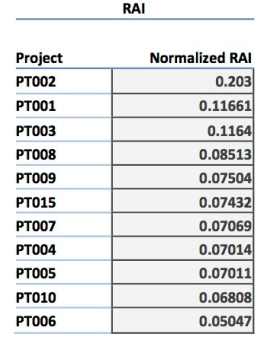

\begin{tabular}{|c|c|c|c|}
\hline Level & \multicolumn{2}{|c|}{ Strategic Objectives } & RWI (\%) \\
\hline \multirow{2}{*}{ Financial } & 01 & CONSOLIDATION & $\mathbf{7 . 2 8}$ \\
\cline { 2 - 4 } & 02 & LEVERAGE & 17.71 \\
\hline Users and & 03 & COMMITMENT & $\mathbf{1 . 4 3}$ \\
\cline { 2 - 4 } Stakeholders & 04 & IMPROVEMENT & $\mathbf{2 3 . 5 6}$ \\
\hline \multirow{2}{*}{ Internal processes } & 05 & GUARANTEE & 10.83 \\
\cline { 2 - 4 } & 06 & MAXIMIZATION & 14.16 \\
\hline \multirow{2}{*}{ Learning and } & 07 & DEVELOPMENT & $\mathbf{1 8 . 0 7}$ \\
\cline { 2 - 4 } Innovation & 08 & PROMOTION & $\mathbf{3 . 4 8}$ \\
\cline { 2 - 4 } & 09 & RESEARCH & $\mathbf{3 . 4 4}$ \\
\cline { 2 - 4 } & \multicolumn{3}{|c}{} \\
\hline
\end{tabular}

\section{Conclusions}

This paper proposes a new methodology for the prioritization of a portfolio of projects based on their expected contribution to the strategic objectives of an organization. The model provides a ranking of projects ordered by their degree of contribution to the achievement of strategic objectives according to the opinion of a group of experts.

The model has been used to analyse the projects portfolio of the Venezuelan corporation Corporación Eléctrica Nacional S.A., particulary to prioritize the Technology Master Plan projects.

The case study also allowed us to determine that according to the priority order of the strategic objectives, the most important projects for the corporation are those that aim to improve commercial management, i.e. the projects that directly generate business value, integration of the company unifying its administrative and management systems and the promotion of an updated technological infrastructure.

\section{Key References}

Dey, P.K., (2006). Integrated project evaluation and selection using multiple-attribute decision-making technique. International Journal of Production Economics 103, 90-103. 
IJAHP Article: Mu, Saaty/A Style Guide for Paper Proposals To Be Submitted to the International Symposium of the Analytic Hierarchy Process 2014, Washington D.C., U.S.A.

Fricke, S.E., Shenhar, A.J., Technol, S., Bloomington, M.N., (2000). Managing multiple engineering projects in a manufacturing support environment. IEEE Transactions on Engineering Management 47 (2), 258-268.

Killen, C.P., Kjaer, C. (2012). Understanding project interdependencies: The role of visual representation, culture and process. International Journal of Project Management. 30(5), 554-566.

Meade L M, Presley A. (2002). R \& D Project Selection using the Analytic Hierarchy Process. IEEE Transactions Engineering Management. 49(1), 59-66.

Srivannaboon, S., Milosevic, D.Z., (2006). A two-way influence between business strategy and project management. International Journal of Project Management 24 (6), 493-505. 